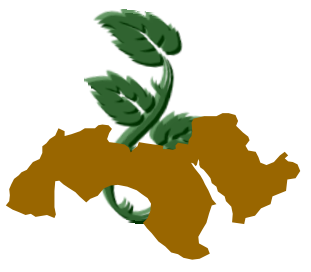

Arab Univ.

\title{
EXOGENOUS APPLICATION OF GLYCINEBETAINE IMPROVES ANTIOXIDANT SYSTEM IN GREEN BEAN (PHASEOLUS VULGARIS) SEEDLINGS UNDER SALINITY STRESS
}

\author{
Hany A.M. Srour ${ }^{1}$ \\ 1- Biochemistry Department, Faculty of Agriculture, Ain Shams University, 68 Hadayek \\ Shoubra, PO box 11241 Cairo, Egypt
}

Keywords: Salinity stress; Glycine betaine; Phasolus valgarus; Antioxidant defensive enzymes

\section{ABSTRACT}

Salt stresses collectively are responsible for many crop losses worldwide especially salt sensitive plants. The present study investigates the roles of exogenous application of glycinebetaine (GB, $5 \mathrm{mM}$ ) in improving salt stress tolerance in salt sensitive green bean seedlings. Salt stresses (45 $\mathrm{mM} \mathrm{NaCl}$ for one week) significantly reduced leaf relative water (RWC) and chlorophyll (chl) content and increased percentage of electrolyte leakage, endogenous Proline and lipid peroxidation. Activities of peroxidase(PX), ascorbate peroxidae (APX), superoxide dismutase (SOD), and catalase (CAT), were significantly increased in shoots and roots of green bean seedlings subjected to salt stress. Exogenous application of GB improves salt tolerance of green been seedlings as shown by increased RWC and chlorophyll contents in leaves and reduced percentage of electrolyte leakage, lipid peroxidation and proline content. Under salinity stress condition, GB application decreased the activities of PX, CAT, APX and SOD in seedling shoots, whereas, it increased the activities of CAT and $A P$ in roots. The result suggests that exogenous application of GB increased green bean seedlings' tolerance to salt-induced oxidative damage by upregulating their antioxidant defense system where this compatible solute protect plant cell against salinity stress.

(Received 14 October, 2014)

(Accepted 4 November, 2014)

\section{INTRODUCTION}

Salinity stress is a widespread environmental problem that has been found to cause large economic losses [Wang et al 2001\& Athar and Ashraf, 2009]. Salinity adversely affects the plant growth and productivity. The nature of damage due to salt stress is complex because it causes both osmotic stress and ionic toxicity. Salinity stress induce oxidative stress through accumulation of prooxidants and reactive oxygen species (ROS) such as singlet oxygen $\left({ }^{1} \mathrm{O}_{2}\right)$, superoxide radical $\left(\mathrm{O}_{2}{ }^{--}\right)$, hydrogen peroxide $\left(\mathrm{H}_{2} \mathrm{O}_{2}\right)$, and hydroxyl radical $\left({ }^{\circ} \mathrm{OH}\right)$. However, the accumulation of ROS is highly dependent on the degree and duration of the imposition of stress and the level of salt tolerance in the plant species. Salt tolerance mechanisms involved development of enzymatic and nonenzymatic antioxidant defense system ready to encounter the deleterious effects of ROS [Hasanuzzaman et al 2011]. The enzymatic system includes ascorbate peroxidase (APX), superoxide dismutase (SOD), catalase (CAT), glutathione peroxidase (GPX), and glutathione $S$-transferase (GST). The nonenzymatic antioxidants include ascorbic acid (AsA), glutathione (GSH), phenolic compounds, alkaloids, nonprotein amino acids, and $\alpha$-tocopherols. Both enzymatic and nonenzymatic antioxidants participate together in scavenging or detoxifying ROS and subsequent protection of plant cells from oxidative damage [Hasanuzzaman et al 2011 and Hasanuzzaman et al 2012]. However, this system acts differently in different plant species and cultivars and it was observed that the enhancement of the antioxidant 
defense system is often correlated with salt stress tolerance [Hasanuzzaman et al 2012 and Hasanuzzaman et al 2013].

Glycine betaine (N,N,N-trimethyl glycine) is not merely a non-toxic, cellular osmolyte that raises intracellular osmolarity when a cell is exposed to stress-induced hyperosmotic conditions: Glycinebetaine (GB) is accumulated during salt stress and play a fundamental role in osmotic adjustment in plants [Szabados and Savouré, 2010]. GB is accumulated in the cytosol without disturbing intracellular biochemistry, which ameliorate the detrimental effects of salinity [Ashraf and Foolad, 2007 - Patade et al 2014]. In many plant species, accumulation of GB was observed as a marker of salt stress tolerance [Ashraf and Foolad, 2007, Ashraf and Harris, 2004]. In many recent reports exogenous applications of GB were found to act as protectants under salt stress condition. [Athar and, Ashraf, 2009, Patade et al 2014, Raza et al 2006].

It has been well documented that, in vitro, GB stabilizes the structures and activities of enzymes and protein complexes and maintains the integrity of membranes against the damaging effects of excessive salt, cold, heat and freezing (Gorham, 1995). Several researchers demonstrated that the level of accumulated GB is highly correlated with the degree of salt tolerance (Rhodes et al 1989; Saneoka et al 1995). Moreover, an exogenous application of GB also increases the salt tolerance of some plants that are otherwise unable to accumulate GB (Harinasut et al 1996; Hayashi et al 1998). Transformation of tobacco with a gene for $\mathrm{CDH}$ i.e gene responsible for glycinebetaine biosynthesis also enhanced plant growth under salt stress, although the level of GB was much lower than that in 'COD- engineered Arabidopsis (Holmström et al 2000). In addition, Brassica juncea and Japanese persimmon (Diospyros kaki) have been successfully transformed to tolerate salt stress through the introduction and over expression of a gene for COD (Gao et al 2000; Prasad et al 2000a). The present study aims to investigate the protective effects of GB on the antioxidant defense in green bean seedlings grown under saline condition.

\section{MATERIALS AND METHODS}

\subsection{Plant Materials and Stress Treatments}

Seeds of green beans (Phaseolus vulgaris cv. Bolista) were purchased from Royal Sluis Co. then, were soaked for $24 \mathrm{~h}$ in the dark on plastic nets upon plastic beakers containing distilled water and kept in the dark at $28 \pm 2^{\circ} \mathrm{C}$ for germination. After $24 \mathrm{~h}$, uniformly germinated seeds were transferred to greenhouse and grown for 15 days in clean sandy soil. Green bean seedlings were then divided into two groups, first group irrigated with tab water and second group irrigated with $45 \mathrm{mM}$ $\mathrm{NaCl}$. Exogenous application of GB was applied on $50 \%$ of seedlings in each group by spraying with $5 \mathrm{mM}$ glycinbetaine solution once daily. Data were taken after one week of salinity treatment. The experiment was repeated five times $(n=5)$ under the same conditions.

\subsection{Measurement of Relative Water Content}

Relative water content (RWC) was measured according to Barrs and Weatherley, (1962). Green bean leaves were weighed (fresh wt, FW) and then immediately floated on distilled water in a petri dish for $8 \mathrm{~h}$ in the dark. Turgid weights (TW) were obtained after drying excess surface water with paper towels. Dry weights (DW) were measured after drying at $80^{\circ} \mathrm{C}$ for $48 \mathrm{~h}$. The calculation was done using the following formula:

$$
\mathrm{RWC}=\frac{\mathrm{FW}-\mathrm{DW}}{T W-D W} X 100
$$

\subsection{Determination of Chlorophyll Content}

Chlorophyll content was determined by homogenizing leaf samples $(0.5 \mathrm{~g})$ with $10 \mathrm{~mL}$ of acetone $(80 \% \mathrm{v} / \mathrm{v})$ followed by centrifuging at $5,000 \times \mathrm{g}$ for $10 \mathrm{~min}$. The absorbance was measured with a UV-visible spectrophotometer at specified wave length and chlorophyll contents were calculated using the equations proposed by Arnon (1949).

\subsection{Determination of Proline Content}

Free proline in seedling tissues were determined protocol of Bates et al (1973) as follows: Fresh leaf tissue $(0.5 \mathrm{~g})$ was homogenized in $10 \mathrm{~mL}$ of $3 \%$ sulfosalicylic acid in ice. The homogenate was centrifuged at $11,500 \times \mathrm{g}$ for $15 \mathrm{~min}$. Two $\mathrm{mL}$ of the filtrate were mixed with $2 \mathrm{~mL}$ of acid ninhydrin and $2 \mathrm{~mL}$ of glacial acetic acid. After incubation at $100^{\circ} \mathrm{C}$ for $1 \mathrm{~h}$ it was cooled and $4 \mathrm{~mL}$ of toluene were added. The optical density of the chromophore containing toluene was read spectrophotometrically at $520 \mathrm{~nm}$ using toluene as a blank. The amount of Proline was determined by comparison with a standard curve.

\subsection{Measurement of Lipid Peroxidation}



bean (Phaseolus vulgaris) seedlings under salinity stress

The level of lipid peroxidation was measured by estimating malonadialdhyde (MDA), using thiobarbituric acid (TBA) as the reactive material following the method of Heath and Packer (1969) with slight modifications. The leaf and root samples $(0.5 \mathrm{~g})$ were homogenized in $3 \mathrm{~mL} 5 \%(\mathrm{w} / \mathrm{v})$ trichloroacetic acid (TCA) and the homogenate was centrifuged at $11,500 \times \mathrm{g}$ for $10 \mathrm{~min}$. One $\mathrm{mL}$ supernatant was mixed with $4 \mathrm{~mL}$ of TBA reagent $(0.5 \%$ of TBA in $20 \%$ TCA). The reaction mixture was boiled at $95^{\circ} \mathrm{C}$ for $30 \mathrm{~min}$ in a water bath and then quickly cooled in an ice bath and centrifuged at $11,500 \times \mathrm{g}$ for $15 \mathrm{~min}$. The absorbance of the colored supernatant was measured at $532 \mathrm{~nm}$ and corrected for nonspecific absorbance at $600 \mathrm{~nm}$. The concentration of MDA was calculated by using the extinction coefficient of $155 \mathrm{mM}^{-1} \mathrm{~cm}^{-1}$ and expressed as $\mathrm{nmol}$ of MDA g $\mathrm{g}^{-1}$ fresh weight.

\section{6- Measurement of electrolyte leakage}

Electrolyte leakage was determined according to the method described by Kong et al (2005). Green bean leaves $(n=10)$ were detached and were individually placed in $50 \mathrm{ml}$ tubes containing $15 \mathrm{ml}$ distilled $\mathrm{H}_{2} \mathrm{O}$ and gently shaken for $2 \mathrm{~h}$. Plants in tubes were then boiled at $100^{\circ} \mathrm{C}$ for 40 $\min$. Plants were then cooled to room temperature and the percentage of electrolyte leakage was determined as the percentage of the conductivity before and after boiling of the detached plants.

\subsection{Determination of Protein}

The protein concentration of each sample was determined according to method of Bradford (1976) using Bovine serum albumin as a protein standard.

\subsection{Enzyme Extraction and Assays}

Using a pre-cooled mortar and pestle, $0.5 \mathrm{~g}$ of leaf tissue was homogenized in $1 \mathrm{~mL}$ of $50 \mathrm{mM}$ icecold K-Phosphate buffer (pH 7.0) containing $100 \mathrm{mM} \mathrm{KCl}, 1 \mathrm{mM}$ ascorbate, $5 \mathrm{mM} \beta$ mercaptoethanol and $10 \%(\mathrm{w} / \mathrm{v})$ glycerol. The homogenates were centrifuged at $11,500 \times g$ for $10 \mathrm{~min}$ and the supernatants were used for determination of enzyme activity. All procedures were performed at $0-4^{\circ} \mathrm{C}$.

\subsubsection{Assay of peroxidase}

Peroxidase (E.c 1.11.1.7) activity in enzyme extract was determined as described by Hammer Schmidt, et al (1982). The reaction mixture (3 $\mathrm{ml})$ consisted of $0.25 \%(\mathrm{~V} / \mathrm{V})$ guiacol in $10 \mathrm{mM}$ sodium phosphate buffer $\mathrm{pH}=6.0$ containing $10 \mathrm{mM} \mathrm{H}_{2} \mathrm{O}_{2}$.
Volume of $25 \mu$ of the crude enzyme extract was added to initiate the reaction. The developed color was measured calorimetrically at $470 \mathrm{~nm}$. The specific activity expressed as $\Delta$ OD. $\mathrm{min}^{-1} \cdot \mathrm{mg}^{-1}$ protein.

\subsubsection{Assay of Superoxide dismutase}

SOD (EC 1.15.1.1) activity was estimated according to Beyer and Fridovich (1987) which was based on xanthine-xanthine oxidase system. The reaction mixture contained $\mathrm{K}$-Phosphate buffer (50 mM), NBT (2.24 mM), catalase (0.1 units), xanthine oxidase $(0.1$ units), xanthine $(2.36 \mathrm{mM})$, and enzyme extract. Catalase was added to avoid the $\mathrm{H}_{2} \mathrm{O}_{2}$-mediated possible inactivation of $\mathrm{CuZn-SOD}$. SOD activity was expressed as units (amount of enzyme required to inhibit NBT reduction by $50 \%$ ). $\mathrm{min}^{-1} \mathrm{mg}^{-1}$ protein.

\subsubsection{Assay of Catalase}

CAT (EC: 1.11.1.6) activity was measured according to the method of Hasanuzzaman et al (2011) by monitoring the decrease of absorbance at $240 \mathrm{~nm}$ for $1 \mathrm{~min}$ caused by the decomposition of $\mathrm{H}_{2} \mathrm{O}_{2}$. The reaction mixture contained $50 \mathrm{mM} \mathrm{K}$ $P$ buffer ( $\mathrm{pH} 7.0$ ), $15 \mathrm{mM} \mathrm{H}_{2} \mathrm{O}_{2}$ and enzyme solution in a final volume of $700 \mu \mathrm{L}$. The activity was calculated using the extinction coefficient of $39.4 \mathrm{M}^{-1} \mathrm{~cm}^{-1}$.

\subsubsection{Assay of Ascorbate peroxidase}

APX (EC: 1.11.1.11) activity was assayed following the method of Nakano and Asada (1981). The reaction buffer solution contained $50 \mathrm{mM} \mathrm{K-P}$ buffer ( $\mathrm{pH}$ 7.0), $0.5 \mathrm{mM}$ AsA, $0.1 \mathrm{mM} \mathrm{H}_{2} \mathrm{O}_{2}, 0.1 \mathrm{mM}$ EDTA, and enzyme extract in a final volume of $700 \mu \mathrm{L}$. The activity was measured by observing the decrease in absorbance at $290 \mathrm{~nm}$ for $1 \mathrm{~min}$ using an extinction coefficient of $2.8 \mathrm{mM}^{-1} \mathrm{~cm}^{-1}$.

\subsection{Statistical Analysis}

All data obtained were subjected to analysis of variance (ANOVA) and the mean differences were compared by a Duncan's multiple range test (DMRT) using SAS (1996) software. Differences at $P<0.05$ were considered significant.

\section{RESULTS}

Table (1) showed that exposure of green bean seedlings to $45 \mathrm{mM} \mathrm{NaCl}$ for one week led to a significant reduction in leaf RWC. Salt stress caused a reduction in RWC in green bean leaves by $14.2 \%$. Exogenous application of GB effectively 
maintained the RWC in salt stressed seedlings. GB could increase RWC by $11.2 \%$ in seedlings exposed to $45 \mathrm{mM} \mathrm{NaCl}$ for one week.

Chlorophyll contents in green bean seedlings decreased markedly as a result to exposure to salinity stress. As shown in Table (1) Chlorophyll content was reduced by $18.9 \%$ due to salt stress treatment in the absence of GB. While chlorophyll content was reduced by only $8.4 \%$ due to the same salt stress treatment in GB treated green bean seedlings. In addition, GB treatment lead to significant increase in chlorophyll contents in non stressed green bean seedlings.

Salt stress caused a remarkable increase in endogenous proline content in green bean seedlings. Proline content increased by $263 \%$ in salt treated green bean seedling. Importantly, exogenous GB could also increase the endogenous Pro content under salt stress condition as well as control. However, the comparative increase was higher in non stressed seedling than salt stressed seedlings.

The content of MDA (indicator of lipid peroxidation) and electrolyte leakage percentage (indicator of cellular membrane damage) highly increased due to salt stress in green bean seedlings as shown in Table (1). Treatment of green bean seedlings with saline solution of $45 \mathrm{mM} \mathrm{NaCl}$ for one week caused increase in the level of lipid peroxidation and electrolyte leakage by about $31 \%$ and $15 \%$ respectively. GB prevents lipid peroxidation and reduces the percentage of electrolyte leakage as indicated in Table (1).

Table (2) showed that salt stress caused significant increase in the activities of PX, CAT, APX, and SOD in shoots and roots of green bean seedlings. Salinity stress caused increase in the activities of antioxidant enzymes in shoots by $15.6 \%$, $15.1 \%, 26 \%$ and $19.3 \%$ in case of PX, CAT, APX, and SOD respectively. In roots of green bean seedlings the activities of antioxidant enzymes were also increased due to exposure to salinity stress by $22.1 \%, 38 \%, 8.6 \%$ and $21 \%$ for PX, CAT, APX, and SOD respectively.

GB treatment reduced the activities of $\mathrm{PX}$, CAT, APX, and SOD in shoots of non-stressed green bean seedlings. In roots, the activities of APX and SOD was not affected by exogenous application of GB. Only activities of PX and CAT were reduced by $\mathrm{GB}$ application. Under salinity conditions, PX, CAT, APX and SOD significantly decreased in seedling shoots. In roots, CAT and APX activities were increased while SOD and PX decreased due to spraying with $5 \mathrm{mM}$ glycine betaine. Moreover, The obtained results clearly demonstrated that GB reduce the activities of CAT, APX and SOD in shoots of salt stressed seedlings to reach the control (non-stressed) levels of these enzymes activities.

\section{DISCUSSION}

Several biochemical and physiological alterations such as decrease in water content in tissues, decline in photosynthetic pigments, and oxidative stress were associated to salinity stress. Salt stress often induce oxidative stress through increasing the generation and reactions of ROS including ${ }^{1} \mathrm{O}_{2}, \mathrm{O}_{2}{ }^{--}, \mathrm{H}_{2} \mathrm{O}_{2}$, and $\mathrm{OH}^{\cdot}$ which is leading to oxidative stress [Hasanuzzaman et al 2012]. However, salinity tolerance in plant cells involved protection of oxidative damage through antioxidant defensive system. GB is a compatible solute which was found to be able to protect the plants from salt-induced damages due to its role of osmoprotection and antioxidant defense (Patade et al 2014). Many researchers indicated that there is a high correlation between accumulations of GB and tolerance to salt stress in many plant species (Raza et al 2006; Hoque et al 2007 and Nounjan et al 2012].

Since salt stress causes osmotic stress, the decline in RWC is a common phenomenon in plants growth under salinity and hence RWC is considered as a good indicator for the level of plant tolerance to salt stress. In the present study, salt stress led to a significant decrease of RWC in green been seedlings treated with $45 \mathrm{mM} \mathrm{NaCl}$ for one week. Similar decrease in RWC due to salt stress was reported in different plant species. The reduction of RWC reflects the limited water availability for different physiological processes. However, when salt stressed seedlings were treated with $\mathrm{GB}, \mathrm{RWC}$ was increased due to the retention of water in the plant tissues (Table, 1). The enhanced water content in plants due to exogenous application of GB was also reported by other researchers (Ashraf and Foolad, 2007; Nawaz and Ashraf, 2007 and El-Samad et al 2011).

Chlorophyll contents in green bean seedlings decreased due to salinity treatment. Salt stress often causes alteration in photosynthetic pigment biosynthesis (Maxwell and Johnson, 2000). Similar decrease in chl content was observed by Yasar et al (2008) in green bean seedlings. However, exogenous application GB in salt treated seedlings 

bean (Phaseolus vulgaris) seedlings under salinity stress

Table 1. Effect of Glycinebetaine on relative water content (RWC), proline, chlorophyll, MDA content and percentage of electrolyte leakage in salt stressed green been seedlings

\begin{tabular}{|ccccccc|}
\hline Treatments & & RWC & $\begin{array}{c}\text { \% of } \\
\text { Electrolyte } \\
\text { lekage }\end{array}$ & $\begin{array}{c}\text { Chlorophyll } \\
\left(\mathrm{mg} \cdot \mathrm{g}^{-1} \cdot \mathrm{FW}\right)\end{array}$ & $\begin{array}{c}\text { Proline } \\
\left(\mathrm{mg} \cdot \mathrm{g}^{-1} . \mathrm{FW}\right)\end{array}$ & $\begin{array}{c}\text { MDA } \\
\left(\mathrm{nmol} \cdot \mathrm{g}^{-1} . \mathrm{FW}\right)\end{array}$ \\
\hline Non Stressed & $-\mathrm{GB}$ & $96.3 \pm 2.33^{\mathrm{a}}$ & $5.3 \pm 0.4^{\mathrm{b}}$ & $0.95 \pm 0.1^{\mathrm{b}}$ & $150.2 \pm 5.5^{\mathrm{d}}$ & $6.25 \pm 0.73^{\mathrm{b}}$ \\
Control) & $+\mathrm{GB}$ & $97.1 \pm 3.4^{\mathrm{a}}$ & $6.1 \pm .55^{\mathrm{b}}$ & $1.2 \pm 0.09^{\mathrm{a}}$ & $245.7 \pm 4.8^{\mathrm{c}}$ & $4.32 \pm 0.24^{\mathrm{c}}$ \\
Salt condition & $-\mathrm{GB}$ & $82.1 \pm 5.6^{\mathrm{c}}$ & $17.2 \pm 1.3^{\mathrm{a}}$ & $0.77 \pm 0.08^{\mathrm{c}}$ & $396.4 \pm 7.1^{\mathrm{b}}$ & $8.2 \pm 0.53^{\mathrm{a}}$ \\
$(45 \mathrm{mM} \mathrm{NaCl})$ & $+\mathrm{GB}$ & $93.3 \pm 4.2^{\mathrm{b}}$ & $7.1 \pm 0.7^{\mathrm{b}}$ & $0.87 \pm 0.1 \mathrm{~b}^{\mathrm{c}}$ & $435.1 \pm 6.7^{\mathrm{a}}$ & $7.1 \pm 0.35^{\mathrm{ab}}$ \\
\hline
\end{tabular}

Each value is the average of five samples \pm SD

Different letters refers to significant differences.

-GB without glycinebetain.

$+\mathrm{GB}$ with glycinebetain $(5 \mathrm{mM})$.

Table 2. Effect of glycine betaine on activities of antioxidant enzymes in shoots and roots of green bean seedlings exposed to salinity stress

\begin{tabular}{|c|c|c|c|c|c|c|c|c|}
\hline \multirow{2}{*}{$\begin{array}{l}\text { ANTIOXIDANT } \\
\text { ENZYMES }\end{array}$} & \multicolumn{4}{|c|}{ SHOOTS } & \multicolumn{4}{|c|}{ ROOTS } \\
\hline & \multicolumn{2}{|c|}{ CONTROL } & \multicolumn{2}{|c|}{$45 \mathrm{mM} \mathrm{NaCl}$} & \multicolumn{2}{|c|}{ CONTROL } & \multicolumn{2}{|c|}{$45 \mathrm{mM} \mathrm{NaCl}$} \\
\hline $\begin{array}{c}\text { Peroxidase } \\
\Delta \text { OD. } \min ^{-1} \cdot \mathrm{mg}^{-1} \\
\text { protein } \\
\text { Catalase }\end{array}$ & $352 \pm 14^{c}$ & $287 \pm 11^{d}$ & $407 \pm 16^{a}$ & $392 \pm 18^{b}$ & $253 \pm 21^{e}$ & $213 \pm 12^{f}$ & $309 \pm 19^{d}$ & $273 \pm 15^{\text {de }}$ \\
\hline $\begin{array}{c}\text { U. } \mathrm{min}^{-1}-\mathrm{mg}^{-1} \\
\text { protein } \\
\text { Ascorbic }\end{array}$ & $0.072 \pm 0.006^{b}$ & $0.061 \pm 0.005^{c}$ & $0.091 \pm 0.006^{a}$ & $0.076 \pm 0.003^{b}$ & $0.018 \pm 0.004^{\mathrm{e}}$ & $0.02 \pm 0.009^{e}$ & $0.025 \pm 0.006^{e}$ & $0.033 \pm 0.007^{d}$ \\
\hline $\begin{array}{c}\text { peroxidase } \\
\Delta \text { OD. } \min ^{-1} \cdot \mathrm{mg}^{-1} \\
\text { protein }\end{array}$ & $9.36 \pm 0.49^{d}$ & $8.65 \pm 0.45^{e}$ & $11.8 \pm 0.43^{d}$ & $10.3 \pm 0 . .33^{d}$ & $21.5 \pm 0.35^{c}$ & $21.9 \pm 0.5^{c}$ & $23.8 \pm 0.61^{b}$ & $24.5 \pm 0.72^{\mathrm{a}}$ \\
\hline $\begin{array}{l}\text { Superoxide } \\
\text { dismutase } \\
\text { U.min } \text { mi-1-mg-1 }^{-1} \\
\text { protein }\end{array}$ & $8.46 \pm 0.25^{\mathrm{e}}$ & $8.33 \pm 0.29^{e}$ & $10.1 \pm 0.19^{d}$ & $8.65 \pm 0.23^{e}$ & $15.7 \pm 0.15^{c}$ & $15.1 \pm 0.27^{c}$ & $18.3 \pm 0.17^{a}$ & $16.9 \pm 0.22^{b}$ \\
\hline
\end{tabular}

could elevate the chl content which might be due to the higher biosynthesis of the pigment. These results are in agreement with Hasanuzzaman et al 2014; Raza et al 2006 and Sakr et al 2012.

Accumulation of Proline in plant tissues is considered as a selection criterion for the stress tolerance of most plant species (Ashraf and Foolad, 2007 and Hayat et al 2012). Our results in Table (1) showed enhanced Proline accumulation in green bean seedling subjected to $45 \mathrm{mM} \mathrm{NaCl}$. Proline accumulation in plant cells exposed to salt is often considered to be involved in stress resistance mechanisms (Aspinall and Paleg, 1981; Yoshiba, et al 1997 and Chen et al 2001). Exogenous foliar application of GB in salt stressed seedlings further enhanced the endogenous Proline content. GB-induced counteraction of salt stress due to enhanced Proline content was re- ported earlier in different plants [Raza et al 2006 and Sakr et al 2012].

Lipid peroxidation is a parameter that determines the oxidative stress. High MDA content is highly correlated to oxidative damage including salinity stress. Data in Table (1) showed that MDA content in green bean seedling increased during salinity stress which is in agreement with other reports (Azooz et al 2009 and Weisany et al 2012). On the other hand, salt stressed seedlings treated with exogenous GB showed lower MDA contents (Table, 1) which was due to their higher antioxidant defense system. Exogenous application of GB-induced upregulation of antioxidant defense and concomitant decrease in MDA content was observed in many plant species including green bean seedlings (Yan et al 2011 and Nounjan et al 2012). 
Electrolyte leakage percentage considered as indicator for cellular membrane damage. Data in Table (1) showed a high correlation between the level of lipid peroxidation expressed as MDA content and the degree of membrane damage in term of percentage of electrolyte leakage. Salt stress caused higher electrolyte leakage due to high lipid peroxidation of cellular membrane. Increment of percentage of electrolyte leakage resulted in lower RWC in plant tissues. Also, GB reduced Electrolyte leakage through its ability to scavenge ROS, upregulation of antioxidant system, and stabilization of cellular membranes.

Salt stress-induced excess generation of ROS and subsequent enhanced activities of many antioxidant enzymes during salt stress have been reported in many plant species. Importantly, the activities of antioxidant enzymes of salt tolerant genotypes are upregulated under salt stress where salt sensitive species failed to do the same [Ghosh et al 2011]. In the present study, antioxidant enzymes showed different responses to salt stress in the presence or absence of exogenous application of GB.

$\mathrm{PX}$ is one of the important enzymes in antioxidant system in plant cells. Peroxidase is responsible for removing $\mathrm{H}_{2} \mathrm{O}_{2}$ by many reducing compounds such as glutathione and phenolic compounds. PX is extremely increased in shoots and roots of green bean seedlings during their exposure to salinity stress. Exogenous application of $5 \mathrm{mM}$ betaine resulted in an increase in PX activity and led to reduction of $\mathrm{H}_{2} \mathrm{O}_{2}$ content, and lipid peroxidation level. These findings together with previous reports suggest that both betaine provide a protective action against salinity-induced oxidative stress by reducing $\mathrm{H}_{2} \mathrm{O}_{2}$ and lipid peroxidation levels and by increasing the antioxidant defense.

Superoxide dismutase is an antioxidant enzyme that removes $\mathrm{O}^{2 \cdot-}$ by catalyzing its dismutation, one $\mathrm{O}^{2 \cdot-}$ being reduced to $\mathrm{H}_{2} \mathrm{O}_{2}$ and another oxidized to $\mathrm{O}_{2}$ (Hasanuzzaman et al 2012). The enhanced activity of SODs minimizes abiotic oxidative stress and has a significant role in the adaptation of a plant to stressed environments (Hasanuzzaman et al 2012). The obtained results in Table (2) indicated that salt stress upregulated the SOD activity in shoots and roots of green bean seedlings. However, foliar application of GB could reduce the activity of SOD in shoots and roots.

Catalase is a potential enzyme which has higher turnover rate and is capable to splite two molecules of $\mathrm{H} 2 \mathrm{O} 2$ to water and oxygen and thus is considered as an efficient ROS detoxifier (Ha- sanuzzaman et al 2012). Data in Table (2) also showed that CAT activity significantly increased in shoots and roots of green bean seedlings due to exposure to salinity stress. The observed increase in CAT activity due to salt stress was in agreement with Yasar et al 2008. On the contrary, Hasanuzzaman et al 2014 found that, in salt tolerant rice the activity slightly increased under mild salt stress (150 $\mathrm{mM} \mathrm{NaCl}$ ) but decreased under severe stress (300 mM NaCl). However, the activity of CAT in the presence of GB under salt treatment was much higher than those under salt treatment without GB which suggest a unambiguous role of $\mathrm{GB}$ in scavenging $\mathrm{H}_{2} \mathrm{O}_{2}$ under salt stress. Similar effects were also observed in several recent studies [Hoque et al 2007; Nawaz and Ashraf, 2010 and Ben Ahmed et al 2010].

Also, APX activity increased in roots of green bean seedlings subjected to salt stress. On the other hand, activity of APX in shoots did not change significantly due to salinity stress. Exogenous spraying of GB reduced the activity of APX in shoots and increased it in roots of salt treated seedlings. This result was in agreement with findings of Patade et al (2014) and Nounjan et al (2012).

\section{Conclusion}

The above results can conclude that exogenous GB is effective protectant to improve shortterm salt tolerance in green bean seedlings (Phaseolus vulgaris). GB effectively maintained better physiological conditions and significantly alleviated oxidative damages of green bean seedlings by enhancing the enzymatic antioxidant defensive system. Considering these facts it can be assumed that GB as salt tolerance inducer in green bean seedlings. Mechanisms of GB as osmoprotectants, free radical scavengers, enzyme activators, or as regulators of other physiological processes were stated in many articles but merely studied under different stress conditions. Studies on their protective mechanisms and signaling cascades are the further scope of research.

\section{5- REFRENCES}

Arnon, D.T. 1949. Copper enzymes in isolated chloroplasts polyphenaloxidase in Beta vulgaris. Plant Physiology, 24: 1-15.

Ashraf, M. and Foolad, M.R. 2007. Roles of glycine betaine and proline in improving plant abiotic stress resistance. Environmental and Experimental Botany, 59(2): 206-216. 

bean (Phaseolus vulgaris) seedlings under salinity stress

Ashraf, M. and Harris, P.J.C. 2004. Potential biochemical indicators of salinity tolerance in plants. Plant Science, 166(1): 3-16.

Aspinall, D. and Paleg L.G. 1981. Proline accumulation: Physiological aspects In Paleg, L.CG. \& D. Aspinall (eds.). The physiology and biochemistry of drought resistance in plants. pp. 205-241. Academic press, Sydney.

Athar, H.R. and Ashraf, M. 2009. Strategies for crop improvement against salt and water stress: an overview. In: Ashraf, M., Ozturk, M. \& Athar, H.R. (eds.). Salinity and Water Stress: Improving Crop Efficiency. Dordrecht, The Netherlands: Springer; pp. 1-16.

Azooz, M.M.; Ismail, A.M. and Elhamd, M.F.A. 2009. Growth, lipid peroxidation and antioxidant enzyme activities as a selection criterion for the salt tolerance of maize cultivars grown under salinity stress. International Journal of Agriculture and Biology, 11(1): 21-26.

Barrs, H.D. and Weatherley, P.E. 1962. A reexamination of the relative turgidity technique for estimating water deficits in leaves. Australian Journal of Biological Science, 15: 413428.

Bates, L.S., Waldren, R.P. and Teare, I.D. 1973. Rapid determination of free proline for waterstress studies. Plant and Soil, 39(1): 205-207.

Ben Ahmed, C., Ben Rouina, B., Sensoy S., Boukhriss M. and Ben Abdullah F. 2010. Exogenous proline effects on photosynthetic performance and antioxidant defense system of young olive tree. Journal of Agricultural and Food Chemistry, 58(7): 4216-4222.

Beyer, W.F. and Fridovich I. 1987. Assaying for superoxide dismutase activity: some large consequences of minor changes in conditions. Analytical Biochemistry, 161(2): 559-566.

Bradford, M.M. 1976. A rapid and sensitive method for the quantitation of microgram quantities of protein utilizing the principle of protein dye binding. Analytical Biochemistry, 72(1-2): 248-254.

Chen, C.T., Men, C.L., Lin C.C. and Kao, C.H. 2001. Regulation of proline accumulation in detached rice leaves exposed to excess copper. Plant Sci., 160: 283-290.

El-Samad, H.M.A., Shaddad, M.A.K. and Barakat, N. 2011. Improvement of plants salt tolerance by exogenous application of amino acids. Journal of Medicinal Plant Research, 5(24): 5692-5699.

Gao, M., Sakamoto, A., Miura, K., Murata, N., Sugiura, A. and Tao, R. 2000. Transformation of Japanese persimmon (Diospyros kaki Thunb.) with a bacterial gene for choline oxidase. Molecular Breeding, 6: 501-510.

Ghosh, N., Adak, M.K., Ghosh, P.D., Gupta, S., Gupta, D.N.S. and Mandal, C. 2011. Differential responses of two rice varieties to salt stress. Plant Biotechnology Reports, 5(1): 89-103.

Gorham, J. 1995. Betaines in higher plants - biosynthesis and role in stress metabolism. In Amino Acids and Their Derivatives in Higher Plants (eds.). R.M. Wallsgrove), pp. 171-203. Cambridge University Press, Cambridge.

Hammerschmidt, R., Nuchles, E.M. and Kuc, J. 1982. Association of enhanced peroxidase activity which induce systemic induced resistance of cucumber to colletotrichum lagenarium. Physiol. Plant Pathol., 20: 73-82.

Harinasut, P., Tsutsui, K., Takabe, T., Nomura, M., Takabe, T. amd Kishitani, S. 1996. Exogenous glycinebetaine accumulation and increased salt-tolerance in rice seedlings. Bioscience, Biotechnology and Biochemistry, 60: 366-368.

Hasanuzzaman, M., Hossain, M.A. and Fujita, M. 2011. Nitric oxide modulates antioxidant defense and the methylglyoxal detoxification system and reduces salinity-induced damage of wheat seedlings. Plant Biotechnology Reports, 5(4): 353-365.

Hasanuzzaman, M., Hossain, M.A., Teixeira, da Silva J.A. and Fujita M. 2012. Plant responses and tolerance to abiotic oxidative stress: antioxidant defense is a key factor. In: Bandi, V., Shanker, A.K., Shanker, C., Mandapaka, M., (eds.). Crop Stress and Its Management: Perspectives and Strategies. Berlin, Germany, Springer; pp. 261-316.

Hasanuzzaman, M., Nahar, K. and Fujita, M. 2014. Plant response to salt stress and role of exogenous protectants to mitigate salt-induced damages. In: Ahmad, P., Azooz, M.M. \& Prasad, M.N.V. (eds.). Ecophysiology and Responses of Plants under Salt Stress. New York, NY, USA: pp. 25-87.

Hasanuzzaman, M., Nahar, K., Alam, M.M., Roychowdhury, R. and Fujita, M. 2013. Physiological, biochemical, and molecular mechanisms of heat stress tolerance in plants. Int. J. Mol. Sci., 14(5): 9643-9684.

Hayashi, H., Alia Sakamoto, A., Nonaka, H., Chen T.H.H. and Murata, N. 1998. Enhanced germination under high-salt conditions of seeds of transgenic Arabidopsis with a bacterial gene 
$(\operatorname{cod} A)$ for choline oxidase. Journal of Plant Research, 111: 357-362.

Hayat, S., Hayat, Q., Alyemeni, M.N., Wani, A.S., Pichtel, J. and Ahmad, A. 2012. Role of proline under changing environments: a review. Plant Signaling and Behavior, 7(11): 111.

Heath, R.L. and Packer, L. 1968. Photoperoxidation in isolated chloroplasts. I. Kinetics and stoichiometry of fatty acid peroxidation. Archives of Biochemistry and Biophysics, 125(1): 189-198.

Holmström, K.O., Somersalo, S., Mandal, A., Palva, E.T. and Welin, B. 2000. Improved tolerance to salinity and low temperature in transgenic tobacco producing glycine betaine. Journal of Experimental Botany, 51: 177185.

Hoque, M.A., Banu, M.N.A. and Okuma, E. 2007. Exogenous proline and glycinebetaine increase $\mathrm{NaCl}$-induced ascorbate-glutathione cycle enzyme activities, and proline improves salt tolerance more than glycinebetaine in tobacco Bright Yellow-2 suspension-cultured cells. Journal of Plant Physiology, 164(11), 1457-1468.

Kong, L., Wang, M. and Bi, D. 2005. Selenium modulates the activities of antioxidant enzymes, osmotic homeodtasis and promotes the growth of sorrel seedlings undersalt stress. Plant growth regulation, 45: 155-163.

Maxwell, K. and Johnson, G.N. 2000. Chlorophyll fluorescence-a practical guide. Journal of Experimental Botany, 51(345): 659-668.

Nakano, Y. and Asada, K. 1981. Hydrogen peroxide is scavenged by ascorbate-specific peroxidase in spinach chloroplasts. Plant and Cell Physiology, 22(5): 867-880.

Nawaz, K. and Ashraf, M. 2007. Improvement in salt tolerance of maize by exogenous application of glycinebetaine: growth and water relations. Pakistan Journal of Botany, 39(5): 1647-1653.

Nounjan, N., Nghia, P.T. and Theerakulpisut, P. 2012. Exogenous proline and trehalose promote recovery of rice seedlings from salt-stress and differentially modulate antioxidant enzymes and expression of related genes. Journal of Plant Physiology, 169(6): 596-604.

Patade, V.Y., Lokhande, V.H. and Suprasanna, P. 2014. Exogenous application of proline alleviates salt induced oxidative stress more efficiently than glycine betaine in sugarcane cultured cells. Sugar Tech., 16(1): 22-29.

Prasad, K.V.S.K., Sharmila, P., Kumar P.A. and Pardha Saradhi P. 2000. Transformation of Brassica juncea (L.) Czern with a bacterial co-
dA gene enhances its tolerance to salt stress. Molecular Breeding, 6: 489-499.

Raza, S.H., Athar, H.U.R. and Ashraf, M. 2006. Influence of exogenously applied glycinebetaine on the photosynthetic capacity of two differently adapted wheat cultivars under salt stress. Pakistan Journal of Botany, 38(2): 241-251.

Rhodes, D., Rich, P.J., Brunk, D.G., Ju, G.C., Rhodes, J.C., Pauly, M.H. and Hansen L.A. 1989. Development of two isogenic sweet corn hybrids differing for glycinebetaine content. Plant Physiol., 91(3):1112-21.

Sakr, M.T., El-Sarkassy, N.M. and Fuller, M.P. 2012. Osmoregulators proline and glycine betaine counteract salinity stress in canola. Agronomy for Sustainable Development, 32(3): 747-754.

Saneoka, H., Nagasaka, C., Hahn, D.T., Yang, W.J., Premachandra, G.S., Joly, R.J. and Rhodes, D. 1995. Salt tolerance of glycinebetaine-deficient and -containing maize lines. Plant Physiology, 107: 631-638.

SAS, 1996. SAS' Procedure Guide "Version 6.12th Ed.," SAS Institute Inc., Cary, NC, USA.

Szabados, L., and Savouré A. 2010. Proline: a multifunctional amino acid. Trends in Plant Science, 15(2): 89-97.

Wang, W., Vinocur, B., Shoseyour, O. and Altman, A. 2011. Biotechnology of plant osmotic stress tolerance: physiological and molecular consideration. Acta Horticulture 590: 286292.

Wang, Y., Yang, L., Zheng, Z., Grumet, R., Loescher, W., Zhu, J.K., Yang, P., Hu, Y. and Chan, Z. 2013. Transcriptomic and physiological variations of three Arabidopsis ecotypes in response to salt stress. PLoS One, 23, 8(7): e69036.

Weisany W., Sohrabi Y., Heidari G., Siosemardeh A., Ghassemi-Golezani K. 2012. Changes in antioxidant enzymes activity and plant performance by salinity stress and zinc application in soybean (Glycine max L.). Plant Omics Journal, 5(2): 60-67.

Yan, Z., Guo, S., Shu, S., Sun, J. and Tezuka, T. 2011. Effects of proline on photosynthesis, root reactive oxygen species (ROS) metabolism in two melon cultivars (Cucumis melo L.) under $\mathrm{NaCl}$ stress. African Journal of Biotechnology, 10(80): 18381-18390.

Yasar, F., Ellialtioglu, S. and Yildiz, K. 2008. Effect of salt stress on antioxidant defense systems, lipid peroxidation, and chlorophyll content in green bean. Russian Journal of Plant Physiology, 55(6): 782-786. 